\title{
ANTIBACTERIAL ACTIVITY OF CLOVE ESSENTIAL OIL AND EUGENOL AGAINST FISH PATHOGENIC BACTERIA ISOLATED FROM CULTURED OLIVE FLOUNDER (Paralichthys olivaceus)
}

\author{
H. N. K. S. Pathirana, S. H. M. P. Wimalasena, B. C. J. De Silva, S. Hossain, Heo Gang-Joon* \\ Laboratory of Aquatic Animal Medicine, Veterinary Medical Center and College of Veterinary Medicine, Chungbuk National University, \\ Chungdae-ro ${ }^{1}$, Seowon-gu, Cheongju, Chungbuk 28644, Korea \\ *Corresponding author, E-mail: gjheo@cbu.ac.kr
}

\begin{abstract}
The antibacterial activity of clove (Syzygium aromaticum) essential oil (CEO) and eugenol was tested against seven Gram-negative and nine Gram-positive fish pathogenic bacteria isolated from cultured olive flounder (Paralichthys olivaceus) in Korea. Eugenol was $>99 \%$ concentrated and CEO consisted of seven chemical compounds including $83.63 \%$ of eugenol. Disk diffusion assay, MIC (minimum inhibitory concentration) and MBC (minimum bactericidal concentration) tests showed CEO and eugenol inhibited the growth of both Gram-negative and Gram-positive bacteria. $\mathrm{CEO}(\mathrm{MBC} / \mathrm{MIC}=1-2)$ and eugenol $(\mathrm{MBC} / \mathrm{MIC}=1-4)$ were bactericidal for all tested strains. The percentage of relative inhibition zone diameter exhibited high values at higher concentration of both CEO and eugenol. Positive correlation was observed between MAR index values and MIC values of $C E O(r=0.61)$ and eugenol $(r=0.15)$. Since antibacterial activity of $C E O$ and eugenol were effective against fish pathogenic bacteria, the use of CEO and eugenol could be advantageous to treat bacterial infections in aquaculture.
\end{abstract}

Key words: antibacterial activity; clove essential oil (CEO); eugenol; fish pathogenic bacteria; olive flounder

\section{Introduction}

Bacterial diseases pose one of the major threats to aquaculture industry worldwide. The crucial bacterial diseases of marine fish in Korea are edwardsiellosis caused by Edwardsiella tarda; streptococcosis caused by Streptococcus iniae, $S$. parauberis, and Lactococcus garvieae; and vibriosis caused by Vibrio harveyi, $V$. ichthyoenteri, and Photobacterium damselae, which have recently increased in cultured fish populations $(1,2)$.

Received:23June 2018

Accepted for publication: 29 October 2018
Disease outbreaks are responsible for elevated mortality rates and decrease of the productivity, causing a high economic loss in olive flounder (Paralichthys olivaceus) aquaculture in Korea (3).

Antibiotics are widely used to treat bacterial infections in fish. However, misuse of antibiotics leads to drug resistance and thereby to the reduced efficacy of the drugs (4). Antibiotics accumulate in the environment and fish, hence pose a potential risk to humans and the environment (5). Therefore, it is essential to develop antibacterial treatments that are made from natural substances. Natural products especially from plants have been investigated for their therapeutic and prophylactic 
effects on several fish diseases (6). Essential oils are one kind of plant products which have been used with their aromatic, flavor, bactericidal, preservative and medicinal properties (7).

One of the most influential antimicrobial medicinal herbs is clove (Syzygium aromaticum) bud belonging to Myrtaceae family, indigenous to India, Indonesia, Zanzibar, Mauritius and Sri Lanka (8). Clove essential oil (CEO) was reported to possess antibacterial, antifungal, insecticidal, and antioxidant properties (9-11). These activities of CEO are mainly due to its high content of phenolic derivatives. Eugenol, a phenylpropene compound with strong biological and antimicrobial activities, is the major constituent of CEO. Eugenol was reported to play an important role in inhibiting the growth of bacteria (12). It can denature protein and react with phospholipids in the cell membrane. It also affects the transport of ions and ATP and changes the fatty acid profile of different bacteria $(13,14)$. Antimicrobial mechanism of eugenol has been found, affecting not only the membrane but also the envelope of fungal and bacterial cells (15).

However, until now no study has been conducted to investigate the antimicrobial property of $\mathrm{CEO}$ and its major component against fish pathogenic bacteria isolated from olive flounder. Therefore, this study was carried out to examine the potential of CEO as well as eugenol as alternatives to commercial antibiotics in aquaculture use.

\section{Materials and methods}

As test strains, seven Gram-negative and nine Gram-positive bacterial strains isolated from Korean cultured olive flounder were used. The Gram-negative strains were E. tarda (FP5060, ED47, Yoshida and ED45), P. damselae (FP4101), $V$. harveyi (FP 8370) and $V$. ichthyoenteri (FP 4004), and the Gram-positive strains were $L$. garvieae (FP5245), S. iniae (FP5228, S186, S530 and S131) and S. parauberis (FP5228, S124, S527 and S1466).They were obtained from Geyongsang National University (Jinju, Korea) and National Institute of Fisheries Science (Busan, Korea). The 100\% pure CEO (Aromarant Co. Ltd., Rottingen, Germany) purified from the bud of clove grown in Zanzibar and the commercial eugenol (>99\%) (Tokyo Chemical Industry Co. Ltd., Tokyo, Japan) were purchased.
The disk diffusion assay with CEO and eugenol was conducted to detect the antimicrobial activity. Sterile disks (Advantec Toyo Kaisha, Ltd., Japan) were impregnated with $20 \mu L$ of CEO and eugenol with different dilutions; [1\%, $5 \%$, $10 \%, 25 \%, 50 \%, 100 \%(\mathrm{~V} / \mathrm{V})]$ and each disk was placed on a Mueller Hinton agar (MB Cell, LA, CA) plate smeared with the test organism. Plates were incubated for $24 \mathrm{~h}$ at $27{ }^{\circ} \mathrm{C}$ to determine the antimicrobial effect. Antibacterial activity was determined by measuring the inhibition zone diameter (IZD) (mm) against each test organism. The antimicrobial activity expressed as percentage of relative inhibition zone diameter (RIZD \%) and it was calculated according to Njau et al. (16) using amoxicillin as a standard antibiotic. The determination of MIC was done using broth micro dilution method with some modifications using different concentrations which 5\% DMSO was used to dissolve CEO and eugenol. The MIC was measured after $24 \mathrm{~h}$ incubation and each test was conducted in triplicates. In order to determine the $\mathrm{MBC}$, the cultured medium from wells which have higher concentration of CEO or eugenol than MIC was smeared on separate Tryptic Soy Agar (TSA) (MB Cell, LA, CA) plates and incubated for $24 \mathrm{~h}$ at $27^{\circ} \mathrm{C}$ (17). The concentration, at which no growth was observed on TSA plate, was determined as the MBC.

Antibiotic susceptibility was determined by disk diffusion method using sixteen antibiotics. Resistance profiles (resistant, intermediate or susceptible) were assigned using criteria described by Clinical and Laboratory Standards Institute (CLSI) (18). Each test was repeated three times. Following the disc diffusion test results of antibiotics, multiple antibiotic resistance (MAR) index was calculated as the ratio of the number of antibiotics to which bacteria was resistant to the total number of antibiotics to which the bacteria was exposed. For the statistical analysis, differences were considered significant at $\mathrm{p}<0.05$. The correlation indices were calculated using the Pearson coefficient ( $r$ ).

\section{Results}

The CEO obtained in the present study constituted $83.63 \%$ of eugenol and other six chemical compounds (Table 1). 
Table 1: Composition of clove essential oil used in this study

\begin{tabular}{lc}
\hline Compound name & Composition \%* \\
\hline Eugenol & 83.63 \\
$\beta$-Caryophyllene & 10.5 \\
a-Humulen & 2.78 \\
Eugenyl-acetate & 1.02 \\
caryophyllene Oxide & 0.39 \\
Cadinene & 0.37 \\
Cadalene & 0.35 \\
\hline
\end{tabular}

*Composition of the essential oil was analysed by Neumond GmbH, Raisting, Germany

IZD of Gram-negative bacteria ranged from 19 to $27 \mathrm{~mm}$ and IZD of Gram-positive bacteria ranged from 15 to $25 \mathrm{~mm}$ in $100 \%(\mathrm{~V} / \mathrm{V})$ of eugenol while IZD of Gram-negative bacteria ranged from 16 to $20 \mathrm{~mm}$ and IZD of Gram-positive bacteria ranged from 14 to $22 \mathrm{~mm}$ at $100 \%(\mathrm{~V} / \mathrm{V})$ of CEO. RIZD $\%$ exhibits high values at higher concentration of both eugenol and CEO (Table 2).

MIC values of the CEO for Gram-negative bacterial strains ranged from 0.125 to $0.5 \%(\mathrm{~V} / \mathrm{V})$ and for Gram-positive strains ranged from 0.25 to $0.5 \%(\mathrm{~V} / \mathrm{V})$. MIC of eugenol for Gram negative bacteria ranged from 0.0312 to $0.0125 \%(\mathrm{~V} / \mathrm{V})$ and for Gram-positive bacteria it was $0.125 \%$ to 1 $\%(\mathrm{~V} / \mathrm{V})$. Mean MBC/MIC for CEO was 1 to 2 and for eugenol it was 1 to 4 (Table 3 ).

The MAR index of four strains [one E. tarda (ED47), one L. garvieae (FP5245), one S. iniae (FP3287) and one S. parauberis (S124)] have been calculated as $\geq 0.2$. The observed Pearson coefficient $(\mathrm{r})$ between the MAR index values and MIC values of eugenol and CEO were $r=0.15$ and $\mathrm{r}=0.61$, respectively (Figure 1).

\section{Discussion}

Many reports have claimed that eugenol is the major compound in the CEO. However, inhibitory activity of clove is due to the presence of several constituents, mainly eugenol, eugenyl acetate and $\beta$ - caryophyllene $(19,20)$. Sohilait (21) reported same composition range of eugenol in clove bud (81.13 - 84.44\%).

According to disk diffusion test result, CEO inhibited the growth of all test bacteria at every concentration except $1 \%$ (Table 2). Chaieb, (22) observed that each bacterial strain demonstrated a significant degree of sensitivity to the CEO, and extensive activity against Gram-positive bacteria, producing a clear zone of inhibition against the majority of the tested strains.

Meanwhile, eugenol was found to be effective against almost all of Gram-negative strains except E. tarda (ED45) strain at every concentration, and the widest IZD was $27 \mathrm{~mm}$ against $V$. ichthyoenteri. Eugenol exhibited higher activity against Gramnegative strains than Gram-positive strains and several studies have reported similar results against pathogenic bacteria $(12,20)$. In another study $(23)$, eugenol showed the highest effect against $S$. aureus compared to the Gram-negative bacterial strains in contrast to the other previous studies.

In comparison, eugenol exhibited highest IZD $(27 \mathrm{~mm})$ against Gram-negative [ $V$. ichthyoenteri (FP 4004)] bacterial strain and CEO exhibited highest IZD $(22 \mathrm{~mm})$ against Gram-positive [S. iniae (S186)] bacterial strain. The inhibition zones induced by the CEO or eugenol were relative to the concentration of eugenol. CEO contains $86.63 \%$ of eugenol as well as six other components, whereas concentration of commercial eugenol was $>99 \%$. The different components of essential oils can act on bacterial proteins using several mechanisms and may affect cell division (14). However, eugenol and CEO were effective against both Grampositive and Gram-negative microorganisms. In every tested fish pathogenic bacteria, the IZD increased in proportion to the eugenol or CEO concentration and the maximum effect was found at $100 \%(\mathrm{~V} / \mathrm{V})$ concentration of both 


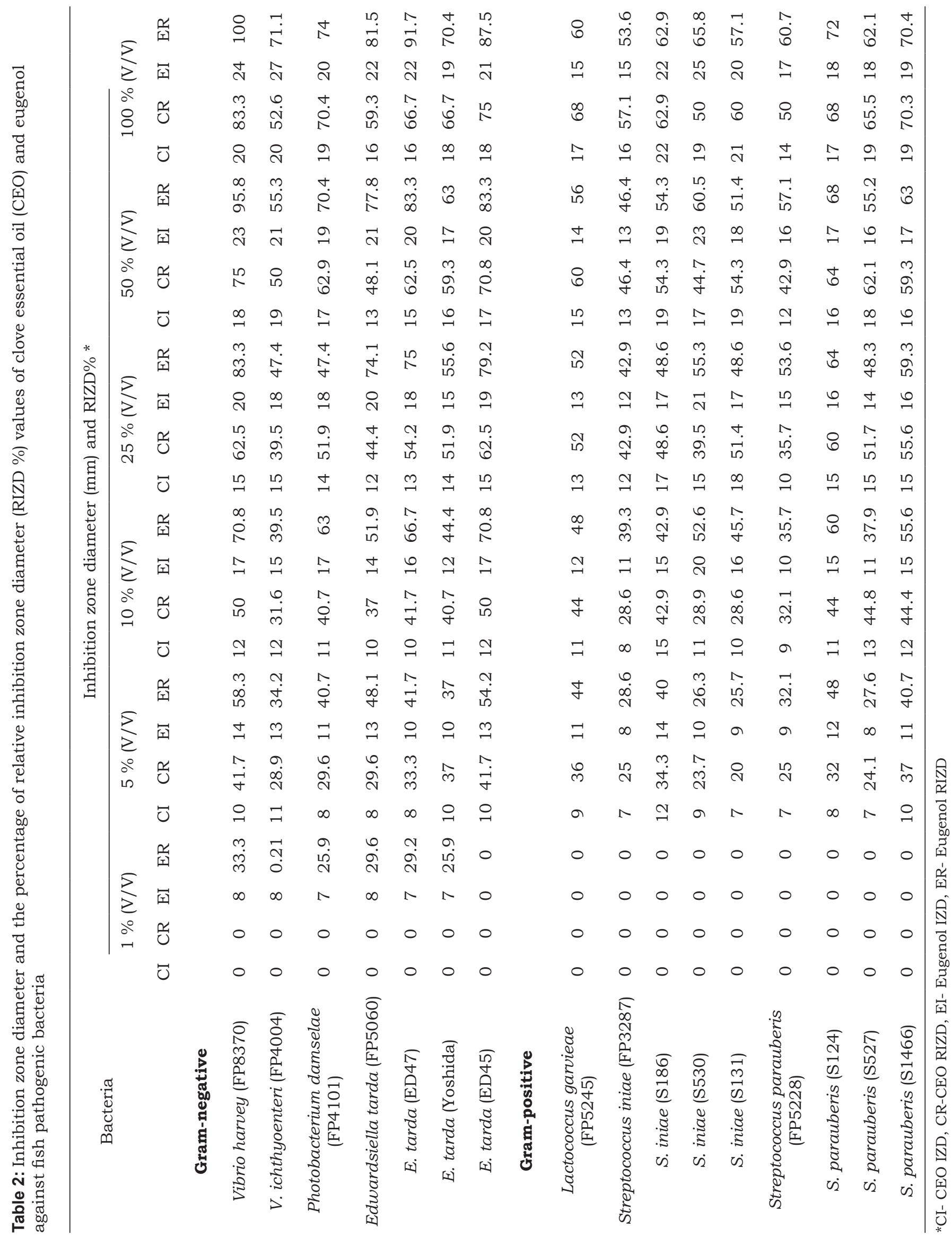


Table 3: Susceptibility pattern of clove essential oil and eugenol against fish pathogenic bacteria

\begin{tabular}{|c|c|c|c|c|c|c|}
\hline \multirow[t]{2}{*}{ Species } & \multicolumn{3}{|c|}{ Clove essential oil } & \multicolumn{3}{|c|}{ Eugenol } \\
\hline & $\begin{array}{c}\text { MIC } \\
(\mathrm{V} / \mathrm{V}) \\
\end{array}$ & $\begin{array}{l}\text { MBC } \\
(\mathrm{V} / \mathrm{V}) \\
\end{array}$ & $\begin{array}{c}\text { MBC/ } \\
\text { MIC }\end{array}$ & $\begin{array}{c}\text { MIC } \\
(\mathrm{V} / \mathrm{V}) \\
\end{array}$ & $\begin{array}{c}\mathrm{MBC} \\
(\mathrm{V} / \mathrm{V}) \\
\end{array}$ & $\begin{array}{c}\mathrm{MBC} / \\
\mathrm{MIC}\end{array}$ \\
\hline \multicolumn{7}{|l|}{ Gram-negative bacteria } \\
\hline Vibrio harveyi (FP8370) & 0.125 & 0.25 & 2 & 0.0312 & 0.125 & 4 \\
\hline V. ichthyoenteri (FP4004) & 0.125 & 0.25 & 2 & 0.0312 & 0.125 & 4 \\
\hline Photobacterium damselae (FP4101) & 0.125 & 0.25 & 2 & 0.125 & 0.25 & 2 \\
\hline Edwardsiella tarda (FP5060) & 0.25 & 0.5 & 2 & 0.0625 & 0.25 & 4 \\
\hline E. tarda (ED47) & 0.5 & 0.5 & 1 & 0.125 & 0.5 & 4 \\
\hline E. tarda (Yoshida) & 0.125 & 0.25 & 2 & 0.125 & 0.25 & 2 \\
\hline E. tarda (ED45) & 0.5 & 0.5 & 1 & 0.125 & 0.5 & 4 \\
\hline \multicolumn{7}{|l|}{ Gram-positive bacteria } \\
\hline Lactococcus garvieae (FP5245) & 0.5 & 1 & 1 & 1 & 1 & 1 \\
\hline Streptococcus iniae (FP3287) & 0.5 & 1 & 2 & 0.5 & 1 & 2 \\
\hline S. iniae (S186) & 0.25 & 0.25 & 1 & 0.5 & 0.5 & 1 \\
\hline S. iniae (S530) & 0.25 & 0.5 & 2 & 0.5 & 0.5 & 1 \\
\hline S. iniae (S131) & 0.25 & 0.25 & 2 & 0.125 & 0.5 & 4 \\
\hline Streptococcus parauberis (FP5228) & 0.5 & 0.5 & 1 & 1 & 1 & 1 \\
\hline S. parauberis (S124) & 0.5 & 0.5 & 1 & 0.5 & 0.5 & 1 \\
\hline S. parauberis (S527) & 0.5 & 0.5 & 1 & 1 & 1 & 1 \\
\hline S. parauberis (S1466) & 0.25 & 0.5 & 2 & 0.5 & 0.5 & 1 \\
\hline
\end{tabular}

Antimicrobial properties (MIC and MBC) were mentioned. MBC/MIC results were used to interpret bacteriostatic or bactericidal activity of oil

Figure 1: Comparative expression of MAR index values and MICs of clove essential oil and eugenol detected for sixteen strains of fish pathogenic bacteria

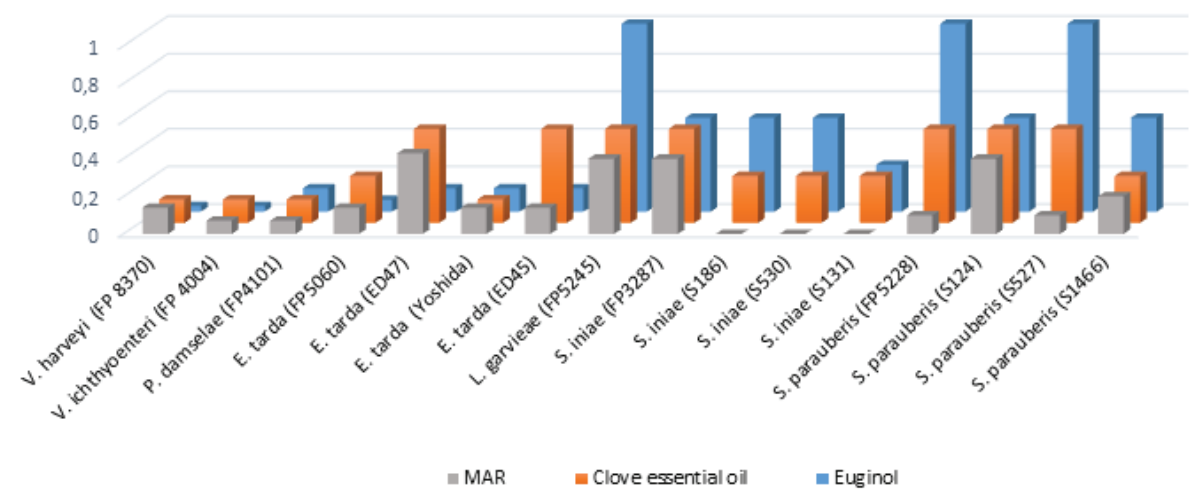


CEO and eugenol. Previous study has reported highest diameter of zone of inhibition of against Staphylococcus aureus followed by Escherichia coli and Listeria monocytogens which were food borne pathogens (24). Fagere (2016) has reported that CEO showed higher IZD against Bacillus subtilis and $S$. aureus (25).

RIZD \% exhibits high values at higher concentrations. All the Gram-negative strains had higher RIZD \% at every concentration of eugenol except E. tarda (ED45). It was observed that eugenol had zero RIZD \% against Gram-positive strains at $1 \%(\mathrm{~V} / \mathrm{V})$ concentration. This indicates that Gram-positive bacteria were not susceptible at every tested concentration of eugenol.

In the present study, the MIC of CEO for Gram-negative bacterial strains ranged from 0.125 to $0.5 \%(\mathrm{~V} / \mathrm{V})$ and for Gram-positive strains ranged from 0.25 to $0.5 \%(\mathrm{~V} / \mathrm{V})$ (Table 3). Eugenol showed lower MIC values than CEO against Gramnegative bacteria which range from 0.0312 to $0.0125 \%(\mathrm{~V} / \mathrm{V})$. According to the $\mathrm{MBC} / \mathrm{MIC}$ ratio, both CEO (MBC/MIC 1-2) and eugenol (MBC/MIC 1-4) demonstrated bactericidal activity against 16 fish pathogenic bacteria. In a previous study, $\mathrm{MBC}$ and MIC values were identical, indicating that the effect of CEO was mainly bactericidal and not bacteriostatic (26) and eugenol demonstrated bacteriostatic activity at lower concentrations and bactericidal activity at slightly higher concentrations against Salmonella $(27,28)$.

The antibiotic resistance profile indicated that all the bacterial strains excluding three strain of S. iniae (S186, S530, and S131) have shown resistance to one or more antibiotics. This was facilitated by MAR index values where all the strains except the three strains mentioned above have been calculated as $\geq 0.07$. The MAR index which is higher than $0.2(>0.2)$ identifies bacteria isolated from a source with a high risk of contamination where antibiotics have been often used (28). The MAR index of four strains [one $E$. tarda (ED47), one L. garvieae (FP5245), one S. iniae (FP3287) and one S. parauberis (S124)] have been calculated as $\geq 0.2$ were noted as comparatively high-risk strains. Finally, the observed Pearson coefficient $(\mathrm{r})$ between the MAR index values and MIC values of eugenol $(r=0.15)$ and CEO $(r=0.61)$ indicated that there is a positive correlation between the CEO or eugenol efficacy and the multidrug-resistance profile of fish pathogenic bacteria (Figure 1).
Although both CEO and eugenol inhibited the growth of tested fish pathogenic bacteria, eugenol could inhibit the growth of bacteria at lower concentrations than CEO. The present study established that both CEO and eugenol are effective against fish pathogenic bacteria isolated from olive flounder and are good candidate for further research to develop a new antibacterial drug against fish pathogenic bacteria. CEO and eugenol can be used to prevent fish diseases by adding to fish feed or immersion treatment. Moreover, in order to apply $\mathrm{CEO}$ and eugenol for treatment of bacterial diseases in aquaculture, the stability of them in the aquatic environment, their digestibility and the toxicity in fish should be further investigated.

\section{Acknowledgements}

The authors declare no conflict of interests. Authors are thankful to Professor Tae-Sung Jung of Institute of Animal Medicine, College of Veterinary Medicine, Gyeongsang National University (Jinju, Korea) and National Institute of Fisheries Science (Busan, Korea) for providing the bacterial strains used in this study.

\section{References}

1. Jee BY, Shin KW, Lee DW, Kim YJ, Lee MK. Monitoring of the mortalities and medications in the inland farms of olive flounder. Paralichthys olivaceus, in South Korea. J Fish Pathol 2014; 27: 77-83.

2. Kim SM, Jun LJ, Park MA, Jung SH, Jeong JB. Monitoring of emaciation disease in cultured olive flounder in Jeju (2010-2013), Korea. Korean J Fish Aquat Sci 2015; 48: 719-24.

3. Nho SW, Shin GW, Park SB, et al. Phenotypic characteristics of Streptococcus iniae and Streptococcus parauberis isolated from olive flounder (Paralichthys olivaceus). FEMS Microbiol Lett 2009; 293: 20-7.

4. Wei LS, Wee W. Chemical composition and antimicrobial activity of Cymbopogon nardus citronella essential oil against systemic bacteria of aquatic animals. Iranian j Microbiol 2013; 5: 14752.

5. Akbary P. In vitro inhibitory activity of the leaf methanol extract of green tea (Camellia sinensis) against Lactococcus garvieae and Aeromonas 
hydrophila isolated of rainbow trout (Oncorhynchus mykiss). Adv Microbiol 2014; 4: 829-34.

6. Pongsak R, Parichat P. Protective effect of clove oil-supplemented fish diets on experimental Lactococcus garvieae infection in tilapia. Biosci Biotechnol Biochem 2009; 73: 2085-9.

7. Burt S. Essential oils: their antibacterial properties and potential applications in foods: a review. Int J Food Microbiol 2004; 94: 223-53.

8. Ayoola1 GA, Lawore1 FM, Adelowotan T, et al. Chemical analysis and antimicrobial activity of the essential oil of Syzigium aromaticum (clove). Afr J Microbiol Res 2008; 2: 162-6.

9. Bakkali F, Averbeck S, Averbeck D, Idaomar M. Biological effects of essential oils: a review. Food Chem Toxicol 2008; 46: 446-75.

10. Huang X, Feng Y, Huang Y, Li H. Chemical composition, antioxidant and the possible use as skin-care ingredient of clove oil (Syzygium aromaticum (L.) Merr. \& Perry) and citronellaoil (Cymbopogon goeringii) from China. J Essent Oil Res 2013; 25: 315-23.

11. Sabahat $\mathrm{S}$, Tariq $\mathrm{P}$. In vitro antibacterial activity of clove against Gram negative bacteria. Pak J Bot 2008; 40: 2157-60.

12. Oyedemi SO, Okoh AI, Mabinya LV, Pirochenva G, Afolayan AJ. The proposed mechanism of bactericidal action of eugenol, terpineol and $\gamma$-terpinene against Listeria monocytogenes, Streptococcus pyogenes, Proteus vulgaris and Escherichia coli. Afr J Biotechnol 2009; 8: 1280-6.

13. Gill AO, Holley RA. Inhibition of membrane bound ATPases of Escherichia coli and Listeria monocytogenes by plant oil aromatics. Int J Food Microbiol 2006; 111: 170-4.

14. Nazzaro F, Fratianni F, Martino LD, Coppola R, FeoVD. Effect of essential oils on pathogenic bacteria. Pharmaceuticals 2013; 6: 1451-74.

15. Bennis S, Chami F, Chami N, Rhayour K, Tantaoui-Elaraki A, Remmal A. Eugenol induces damage of bacterial and fungal envelope. Moroccan J Biol 2004; 1: 33-9.

16. Njau EA, Alcorn J, Ndakidemi P, Chirino-Trejo M, Buza J. Antimicrobial and antioxidant activity of crude extracts of Rauvolfia caffra var. caffra (Apocynaceae) from Tanzania. Int J Biol 2014; 6: 156-67.

17. Hammer KA, Carson CF, Riley TV. Antimicrobial activity of essential oils and other plant extracts. J Appl Microbiol 1999; 86: 985-90.

18. CLSI. Performance standards for antimicrobial susceptibility testing of bacteria isolat- ed from aquatic animals: second informational supplement. CLSI document VET03/VETO4-S2. Wayne, PA : Clinical and Laboratory Standards Institute, 2014.

19. Seongwei L, Musa N, Wee W, Musa N. Chemical composition and antimicrobial activity of the essential oil of Syzygium aromaticum flower bud (clove) against fish systemic bacteria isolated from aquaculture sites. Front Agric China 2009; 3: 332-6.

20. Cortés-Rojas DF, de Souza CRF, Oliveira WP. Clove (Syzygium aromaticum): a precious spice. Asian Pac J Trop Biomed 2014; 4: 90-6.

21. Sohilait HJ. Chemical composition of the essential oils in Eugenia caryophylata, thunb from Amboina Island. Sci J Chem 2015; 3: 95-9.

22. Chaieb K, Hajlaoui $H$, Zamantar T, et al. The chemical composition and biological activity of clove essential oil, Eugenia caryophyllata (Syzigium aromaticum L. Myrtaceae): a short review. Phytother Res 2007; 21: 501-6

23. Rehab MA, Zeinab SH. Eugenol and linalool: comparison of their antibacterial and antifungal activities. Afr J Microbiol Res 2016; 10: 1860-72.

24. Bharath MR, Azeem MA, Keerthan HV. Antimicrobial activity of clove extracts against food borne pathogens Escherichia.coli, Salmonella. tyhimurium, Staphylococcus aureus and Listeria monocytogenes and GC-MS analysis of extracts. Int J Pharm Bio Sci 2017; 8: 321-9.

25. Fagere ZO, Zoheir A, Magboul A. Antibacterial activity of clove oil against some microorganisms at Khartoum State. Adv Med Plant Res 2016; 4: 122-8.

26. Shahavi MH, Hosseini M, Jahanshahi M, Meyer RL, Darzi GN. Clove oil nanoemulsion as an effective antibacterial agent: Taguchi optimization method. Desalin Water Treat 2015; 57: 18379-90.

27. Devi KP, Nisha SA, Sakthivel R, Pandian SK. Eugenol (an essential oil of clove) acts as an antibacterial agent against Salmonella typhi by disrupting the cellular membrane. J Ethnopharmacol 2010; 130: 107-15.

28. Chitanand MP, Kadam TA, Gyananath G, Totewad ND, Balhal DK. Multiple antibiotic resistance indexing of coliforms to identify high risk contamination sites in aquatic environment. Indian J Microbiol 2010; 50: 216-20. 


\title{
PROTIBAKTERIJSKA AKTIVNOST ETERIČNEGA OLJA NAGELJNOVIH ŽBIC IN EVGENOLA PROTI PATOGENIM BAKTERIJAM RIB, IZOLIRANIH IZ GOJENEGA MORSKEGA LISTA (Paralichthys olivaceus)
}

\author{
H. N. K. S. Pathirana, S. H. M. P. Wimalasena, B. C. J. De Silva, S. Hossain, Gang-Joon Heo
}

Povzetek: Protibakterijsko delovanje eteričnega olja nageljnovih žbic(Syzygiumaromaticum)(CEO) in evgenola je bilo testirano pri sedmih vrstah po Gramu negativnih in devetih vrstah po Gramu pozitivnih patogenih bakterij, ki so bile izolirane iz gojenega morskega lista (Paralichthys olivaceus) v Južni Koreji. Evgenol je bil 99-odstotno koncentriran, CEO pa je sestavljalo sedem kemičnih spojin, med njimi je bilo največ evgenola, ki je predstavljal 83,odstotka eteričnega olja.

Metoda difuzije v trdem gojišču, minimalna zaviralna koncentracija (MIC) in minimalna baktericidna koncentracija (MBC) so pokazale, da sta CEO in evgenol zavirala rast tako po Gramu negativnih kot po Gramu pozitivnih bakterij. $\mathrm{CEO}$ (MBC/MIC=1-2) in evgenol (MBC/MIC = 1-4) sta bila baktericidna za vse testirane seve. Odstotek velikosti relativne zaviralne cone je bil visok pri višji koncentraciji CEO in evgenola. Pozitivna soodvisnost je bila opažena med vrednostmi indeksa MAR in vrednostmi MIC pri CEO $(r=0,61)$ in evgenolu $(r=0,15)$. Ker sta CEO in evgenol pokazala učinkovito delovanje proti patogenim bakterijam rib, bi bila uporaba CEO in evgenola lahko uporabna za zdravljenje bakterijskih okužb v ribogojništvu.

Ključne besede: antibakterijsko delovanje; eterično olje klinčkov (CEO); evgenol; patogene bakterije rib; morski list 